\title{
Some Local Names for certain Plants in Golden Valley Herefordshire
}

\section{Harriet G. M. Murray-Aynsley}

To cite this article: Harriet G. M. Murray-Aynsley (1896) Some Local Names for certain Plants in Golden Valley Herefordshire, Folklore, 7:1, 91-91, DOI: 10.1080/0015587X.1896.9720345

To link to this article: http://dx.doi.org/10.1080/0015587X.1896.9720345

曲 Published online: 14 Feb 2012.

Submit your article to this journal \lceil

Џll Article views: 1

Q View related articles $\longleftarrow$ 
Sode local Names for certain Plants in Golden Valley HEREFORDSHIRE.

$\begin{array}{llll}\begin{array}{l}\text { Local Name. } \\ \text { Snafpers }\end{array} & \text {. } & \text {. } & \text { Stitchwort. } \\ \text { Ransom } & \text {. } & \text {. } & \text { Wild garlic. } \\ \text { Jack-in-the-hedge } & \text {. } & \text {. } & \text { Treacle-mustard. } \\ \text { Butcher } & \text {. } & \text {. } & \text { Early purple orchis } \\ \text { Whitsun Boss } & \text {. } & \text {. } & \text { Guelder rose. }\end{array}$

Harriet G. M. Murray-Aynsley.

Nortu Indian Notes and Queries, Vol. IV.

Popular Religion and Anthropology.

379. The Banjaras of the Deccan.-Reprint of a pamphlet by MIr. Cumberlege (12 pp.). $\Lambda$ gipsy tribe. Their castes and divisions; dress; rites; religion. The following are some sub. headings :

Mathurias.-Marriage : Money paid to bride's father; groom's father gives a feast to bride's village. Betrothal takes place in early childhood, and after it the girl can marry no other than her betrothed. The boy and all adults who can, ride to the bride's hamlet; a feast takes place. Clothes of the pair knotted together, with money and rice in the knot. Walking round a curtain. The pair change seats. When the girl goes to her groom's hamlet she draws water, which is mixed with water drawn by one of his female relations; with this, food is cooked; the bride, hitherto considered of no caste at all, becomes one of her groom's caste.

Funeral: If a male die before the sacred thread has been put on, he is buried; if after, burnt. Unmarried girls buried, wives burnt.

Labanas.-Marriage: Women unclean thrce days after childbirth. Widows may not re-marry.

Funeral: Children below one year of age are buried; others burnt.

Charans.-Professional dacoits.

Marriage: A ccrtain chant recited, after which the groom's loft arm is pierced with a red-hot needle. Partial exogamy. 